\title{
Surface Properties and Flotation Characteristics of Boron Minerals
}

\author{
Orhan Özdemir ${ }^{1}$ and Mehmet S. Çelik ${ }^{2, *}$ \\ ${ }^{I}$ The University of Queensland, School of Chemical Engineering, Brisbane, Queensland, Australia \\ ${ }^{2}$ Istanbul Technical University, Mineral Processing Department, Ayazaga, Istanbul, Turkey
}

\begin{abstract}
Flotation of soluble salt minerals such as potash, trona and borax exhibits similarities because all are conducted in their brine solutions. The most commercially important boron minerals in the world are borax $\left(\mathrm{Na}_{2} \mathrm{~B}_{4} \mathrm{O}_{7} .10 \mathrm{H}_{2} \mathrm{O}\right)$, colemanite $\left(\mathrm{Ca}_{2} \mathrm{~B}_{6} \mathrm{O}_{11} .5 \mathrm{H}_{2} \mathrm{O}\right)$, ulexite $\left(\mathrm{NaCaB}_{5} \mathrm{O}_{9} .8 \mathrm{H}_{2} \mathrm{O}\right)$, and kernite $\left(\mathrm{Na}_{2} \mathrm{~B}_{4} \mathrm{O}_{7} \cdot 4 \mathrm{H}_{2} \mathrm{O}\right)$. Most of them contain low grades when mined and must be upgraded by mineral processing techniques to commercially acceptable quality for the production of basic chemicals, such as boric acid. Boron minerals exhibit a spectrum of solubilities depending upon the cations in the lattice structure. Accordingly, a classification of semi-soluble (colemanite and ulexite) and soluble (borax and kernite) boron minerals may be appropriate as each class of minerals behaves differently in flotation. While borax has to be concentrated from its saturated brine, colemanite and ulexite can be recovered by flotation as is the case for other semi-soluble salt minerals. A common problem encountered in both classes of boron minerals is the presence of significant amounts of clay type minerals which adversely affect flotation recoveries in the form of slime coating. Despite the successful application of flotation technology in the potash industry, flotation has not yet been well developed for boron recovery. This may be attributed to inherent difficulties such as high ionic strengths, high viscosity brines, interaction of cations at the solid/liquid interface, and particularly the presence of clay minerals acting as persistent slimes. In this paper, we have reviewed the flotation chemistry studies on the interaction of boron minerals with anionic (sodium dodecylsulfate) and cationic (dodecylamine hydrochloride) surfactants along with the electrokinetics properties of boron minerals.
\end{abstract}

Keywords: Boron minerals, flotation, beneficiation, colemanite, borax, borates.

\section{INTRODUCTION}

Boron compounds are used in the manufacture of a variety of industrial products including advanced materials. The total world boron ore reserves are estimated to be equivalent to 1,241 million tons of $\mathrm{B}_{2} \mathrm{O}_{3}$ [1]. The United States and Turkey are the world's two largest producers of boron compounds. Together, these two countries make up about $90 \%$ of the world's boron reserves [2].

Boron minerals show a spectrum of solubilities depending on the cations in the lattice structure. While colemanite and ulexite are classified as semi-soluble minerals, borax and kernite are soluble minerals. Borax $\left(\mathrm{Na}_{2} \mathrm{~B}_{4} \mathrm{O}_{7} \cdot 10 \mathrm{H}_{2} \mathrm{O}\right)$, one of the most important boron minerals in the world, contains about $20 \% \mathrm{~B}_{2} \mathrm{O}_{3}$ when mined, and must be upgraded to about $35 \% \mathrm{~B}_{2} \mathrm{O}_{3}$ for the production of basic chemicals, such as borax penta hydrate. The most commercially important boron minerals beside borax are colemanite $\left(\mathrm{Ca}_{2} \mathrm{~B}_{6} \mathrm{O}_{11} .5 \mathrm{H}_{2} \mathrm{O}\right)$, ulexite $\left(\mathrm{NaCaB}_{5} \mathrm{O}_{9} \cdot 8 \mathrm{H}_{2} \mathrm{O}\right)$, and kernite $\left(\mathrm{Na}_{2} \mathrm{~B}_{4} \mathrm{O}_{7} \cdot 4 \mathrm{H}_{2} \mathrm{O}\right)$. Apart from these minerals, a considerable amount of boron compounds is also produced from boron-rich lakes [3].

Borax is normally concentrated from its saturated brine by scrubbing followed by classification. The friable nature of boron minerals, however, tends to produce a large amount of fines mostly below $0.2 \mathrm{~mm}$ which are usually discarded

\footnotetext{
*Address correspondence to this author at the Istanbul Technical University, Mineral Processing Department, Ayazaga, Istanbul, Turkey; Tel: +90 212 2856128; Fax: +90 212 2856345; E-mail: mcelik @itu.edu.tr
}

as waste. Recovery of these fines is possible only through particle separation processes such as flotation. In most boron ores, the major accompanying gangue minerals are montmorillonite type clays and carbonate minerals, and thus a common problem encountered in both classes of boron minerals is the presence of significant amounts of clay type minerals which adversely affect flotation recoveries in the form of slime coatings [4].

While borax has to be concentrated from its saturated brine, for the semisoluble colemanite and ulexite minerals, different recovery strategies need to be employed. Despite the successful application of flotation technology in the potash industry, flotation has not yet been well developed for borax recovery. This may be attributed to inherent difficulties such as high ionic strengths, high viscosity brines, and particularly the presence of clay minerals, which act as persistent slimes.

There have been many models proposed to explain the flotation behavior of soluble salts in their saturated solutions such as ion exchange [5], a heat of solution [6], and a surface charge-ion pair models [7-9]. Recently, significant progress has been achieved in the areas of soluble salt flotation chemistry particularly by Miller and his co-workers [8-11]. Subsequently a research by Hancer et al. showed that consideration of hydration phenomena at salt crystal surfaces provides a better explanation for the flotation of soluble salts even when the collector is charged the same as the salt [11]. Recent studies with soluble salts showed that the flotation of 
soluble salts depends on their structure breaking and making properties [11-15]. These studies indicated that a salt may be either a water structure maker or a water structure breaker. While Miller and his co-workers provided new insight into explaining the selective flotation of several soluble salt minerals from their saturated brines, Celik and his associates on the other hand have identified some particular characteristics of the flotation behavior of boron minerals with cationic and anionic collectors [16-19].

In this paper, we have reviewed the interaction of boron minerals with anionic and cationic surfactants, and their relevance to flotation.

\section{EXPERIMENTAL}

\subsection{Materials}

The colemanite/ulexite minerals used in this review paper were obtained from the Bigadic and Kestelek deposits and Kirka borax deposits of Turkey. The $150 \times 74$ micrometer size fraction was used for microflotation studies [20]. The fine fraction (less than 38 micrometer) was used for zeta potential measurements. High purity dodecylamine hydrochloride (DAH) purchased from Eastman Kodak Co, and sodium dodecyl sulfate (SDS) purchased from Fluka were used as collectors in this study. The $\mathrm{pH}$ was adjusted by $\mathrm{HCl}$ and $\mathrm{NaOH}$. Other organic chemicals, $\mathrm{NaCl}, \mathrm{KCl}, \mathrm{CsCl}$, $\mathrm{BaCl}_{2}, \mathrm{CaCl}_{2}$, and $\mathrm{MgCl}_{2}$ were all ACS certified. Distilled and deinozed water of $1-2.10^{-6} \mathrm{microohm} / \mathrm{cm}$ conductivity was used in all experiments.

\subsection{Methods}

\subsubsection{Flotation Experiments}

The microflotation tests were carried out in a $150-\mathrm{mL}$ column cell $(25 \times 220 \mathrm{~mm})$ with a 15 micrometer frit and magnetic stirrer. The samples of $1 \mathrm{~g}$ of boron mineral were conditioned in a 150 -mL solution containing the desired collector for $10 \mathrm{~min}$ and then floated for $1 \mathrm{~min}$ with nitrogen gas at a flow rate of $50 \mathrm{~cm}^{3} / \mathrm{min}$. An automatically controlled microflotation apparatus was used to control nitrogen flow rate and flotation time [20]. In the case of microflotation tests with clay, the mixture was composed of $1 \mathrm{~g}$ of salt mineral and $0.1 \mathrm{~g}$ clay.

The microflotation tests with ultrasonic treatment were carried out in an ultrasonic bath. In this method, the sample was conditioned for 9 min by magnetic stirring followed by in situ ultrasonic conditioning (the microflotation cell was placed in the ultrasonic bath).

\subsubsection{Electrokinetic Measurements}

The electrokinetic measurements at intermediate ionic strengths were conducted by a Zeta Meter 3.0 equipped with a microprocessor unit to directly calculate the $\zeta$ potential. One gram of colemanite in $100 \mathrm{~mL}$ of solution was conditioned for $10 \mathrm{~min}$. The suspension was kept still for $5 \mathrm{~min}$ to let larger particles settle. Each data point is an average of approximately 10 measurements. All measurements were made at ambient temperature and converted to $22 \pm 1^{\circ} \mathrm{C}$ temperature at which flotation tests were performed. At high ionic strengths where the conventional Zeta Meters failed to function, the phase analysis light-scattering technique (PALS) was used. In this technique, phase modulation is applied so that the Doppler frequency for a particular zeromobility particle is equal to the modulation frequency $\omega_{0}$. It is possible then to measure the deviation of the actual frequency present in the scattered light by performing a phase comparison of the detected signal with the imposed modulator frequency. If the mobility is truly zero, the relative phase of the two will be constant: if a small mobility is present, the relative phase will be shifted, and a small phase shift can be detected by a phase comparator.

\section{ELECTROKINETIC PROPERTIES OF THE BORON MINERALS}

\subsection{Dissolution of Boron Minerals}

As mentioned before, boron minerals exhibit a spectrum of different chemical compositions with cations ranging from monovalent to multivalent ions. The type and valency of the cation dictate the solubility of the mineral and in turn controls its electrokinetic behavior. Salt type minerals such as borates release a number of species upon dissolving in water [21, 22]. For example, colemanite containing $\mathrm{Ca}^{2+}$ ion in its structure undergoes acid base reactions in the vicinity of $\mathrm{pH}$ 9.3. The following overall dissolution process for colemanite occurs in a system open to the atmosphere [17]:

$2 \mathrm{CaO} .3 \mathrm{~B}_{2} \mathrm{O}_{3} .5 \mathrm{H}_{2} \mathrm{O}+4 \mathrm{CO}_{2}+6 \mathrm{H}_{2} \mathrm{O} \Leftrightarrow 2 \mathrm{Ca}^{2+}+6 \mathrm{H}_{3} \mathrm{BO}_{3}+$ $4 \mathrm{HCO}_{3}{ }^{-}$

Similarly, ulexite dissolves in water in the presence of $\mathrm{CO}_{2}$ : [2]

$\mathrm{NaCaB}_{5} \mathrm{O}_{9} \cdot 8 \mathrm{H}_{2} \mathrm{O}+3 \mathrm{CO}_{2}+6 \mathrm{H}_{2} \mathrm{O} \Leftrightarrow \mathrm{Na}^{+}+\mathrm{Ca}^{2+}+5 \mathrm{H}_{3} \mathrm{BO}_{3}^{-}$ $+3 \mathrm{HCO}_{3}{ }^{-}+5 \mathrm{H}_{2} \mathrm{O}$

On the other hand, the highly soluble borax will dissolve according to the following reaction [3]:

$2 \mathrm{Na}_{2} \mathrm{~B}_{4} \mathrm{O}_{7} \cdot 10 \mathrm{H}_{2} \mathrm{O} \Leftrightarrow 4 \mathrm{Na}^{+}+\mathrm{B}_{4} \mathrm{O}_{7}{ }^{2-}+\mathrm{HB}_{4} \mathrm{O}_{7}^{-}+\mathrm{OH}^{-}+$ $9 \mathrm{H}_{2} \mathrm{O}$

The solubilities of colemanite, ulexite and borax at $20^{\circ} \mathrm{C}$ are $5.10^{-3} \mathrm{M}(2.1 \mathrm{~g} / \mathrm{L}), 1.5 .10^{-2} \mathrm{M}(6.1 \mathrm{~g} / \mathrm{L}$,$) , and 0.11 \mathrm{M}$ $(41.9 \mathrm{~g} / \mathrm{L})$, respectively $[17,23-26]$.

\subsection{Electrokinetic Properties of Boron Minerals with Respect to $\mathrm{pH}$ in the Absence of Surfactants}

Sparingly soluble minerals when dissolved in water will release a number of species into solution. These ionic species will adsorb at the solid-liquid interface or may form in solution and subsequently adsorb on the solid in amounts proportional to their concentrations. The electrokinetic behavior is an indicator of the ability of ions to be incorporated in the double layer and, in particular, may reveal the expected flotation response for a certain collector scheme. The electrokinetic behavior of boron minerals has been characterized in terms of the $\mathrm{pH}$ of their iso-electric point (iep) and also of potential-determining ions. Figs. (1 and 2) show the zeta potential profile of a series of boron minerals in water as a function of $\mathrm{pH}$ [17]. The maximum ionic strength used in all measurements was below $0.1 \mathrm{M}$. The percent solid was kept at $1 \%$.

As seen from the results, the iep of colemanite is found to occur at $\mathrm{pH}$ 10.5; however, inderite (magnesium borate) and tunellite (strontium borate) show positive zeta potentials throughout the $\mathrm{pH}$ range with no clear iep. On the other 
hand, the iep of borax, similar to ulexite, appears to be absent or impossible within the $\mathrm{pH}$ range of stability. Unlike other boron minerals, borax and ulexite are found to exhibit negative charges in $\mathrm{pH}$ range of interest. Further studies showed that the potential determining ions (pdi) for boron minerals are found to be the constituent lattice cations, i.e., $\mathrm{Ca}^{2+}$ (for colemanite) and the anion $\mathrm{B}_{4} \mathrm{O}_{7}^{2-}$ (borate), and the $\mathrm{H}^{+}$and $\mathrm{OH}^{-}$ions which control ratio of $\mathrm{HCO}_{3}{ }^{-} / \mathrm{CO}_{3}{ }^{2-}[17$, 24].

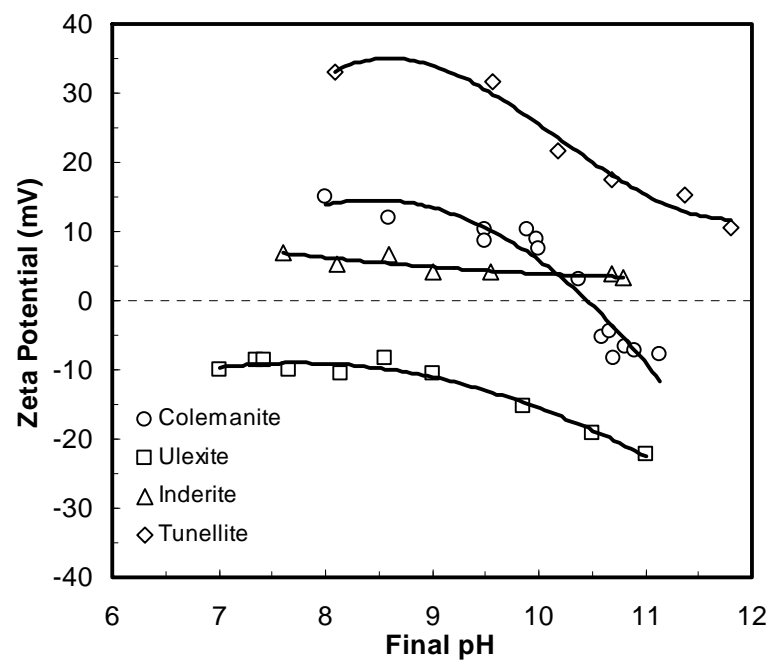

Fig. (1). Zeta potential profiles of some boron minerals [17].

Meanwhile, previous studies also showed that the solid concentration has been found to be an important parameter in controlling the magnitude and even the sign of the zeta potential measurements [18]. $\mathrm{Ca}^{2+}$ ion releases depend on the amount of solid added. Therefore, the zeta potential of colemanite varies considerably with changes in solid concentration [17]. In order to obtain reliable zeta potential results, the measurements should be either conducted at solid concentrations more than $1 \%$ or the conditioning period be kept long enough to let all $\mathrm{Ca}^{2+}$ ions released.

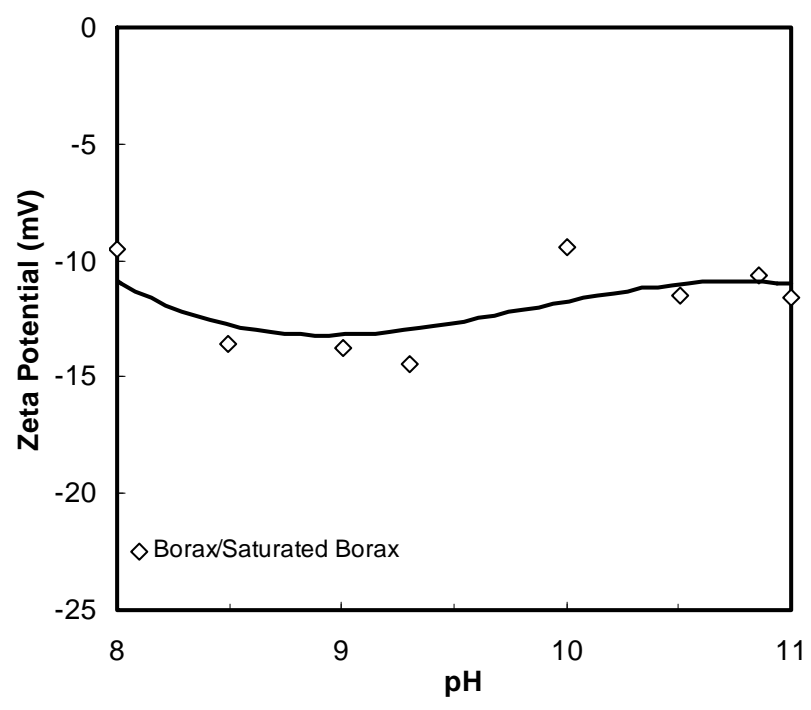

Fig. (2). Zeta potential of borax as a function of $\mathrm{pH}$ [27].

\subsection{Electrokinetic Properties of Boron Minerals in the Presence of Surfactants}

Fig. (3) shows the zeta potentials of colemanite in the absence and presence of anionic (SDS) and cationic (DAH) surfactants. The isoelectric point (iep) of colemanite in the presence of $2.10^{-3} \mathrm{M} \mathrm{NaCl}$ was determined to be approximately 10.5. The addition of SDS makes the colemanite surface slightly less negative below the iep. Above the iep, in the presence of SDS, the zeta potentials of colemanite approaches to that in the absence of SDS. This indicates that some adsorption of alkylsulfonate occurs below the iep and continues to decrease above it. The marginal change in the zeta potentials can be ascribed to the large quantities of $\mathrm{Ca}^{2+}$ ions in the solution that are offset by the equivalent concentrations of alkylsulfonate. Since the alkylsulfonate concentration is insufficient to balance the excess positive charges, the net charge changes marginally.

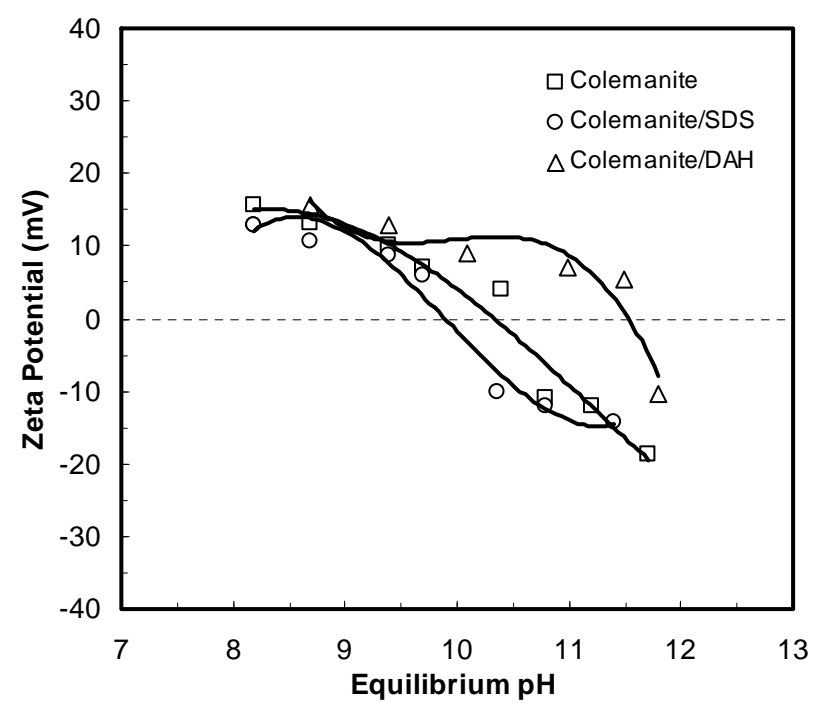

Fig. (3). Zeta potential of colemanite in the presence of surfactants [18].

Similarly, DAH makes the surface slightly positive below the iep, followed by a gradual increase in positive charges above the iep of colemanite. The charge reversal to positive occurs at $\mathrm{pH}$ 11.6. Also, in this study at the amine concentration of $5.10^{-5} \mathrm{M}$, bulk precipitation of amine was visually observed above $\mathrm{pH} 10$. Since the solubility of DAH [28] is $2.10^{-5} \mathrm{M}$ above $\mathrm{pH} 10.5$, the surface precipitation of amine may slightly affect the zeta potential measurements.

Fig. (4) shows the zeta potential of colemanite vs. the reagent concentration. Up to a surfactant concentration of $3.10^{-4} \mathrm{M}$ SDS, colemanite exhibits positive potentials. Beyond this concentration, however, it undergoes a charge reversal. Computations based on $\mathrm{Ca}^{2+}$ ion measurements in colemanite supernatant $\left(2.10^{-3} \mathrm{M}\right)$ show that the onset of charge reversal apparently corresponds to the solubility of $\mathrm{Ca}(\mathrm{DS})_{2}$, which is reported to be $1.2 .10^{-10} \mathrm{M}$ [29]. Similarly, DAH also exhibits positive zeta potentials in the same concentration region as SDS, followed by a sharp increase in DAH concentration. Again, this point $\left(2.10^{-4} \mathrm{M}\right)$ represents the solubility limit of DAH at this particular $\mathrm{pH}$. 


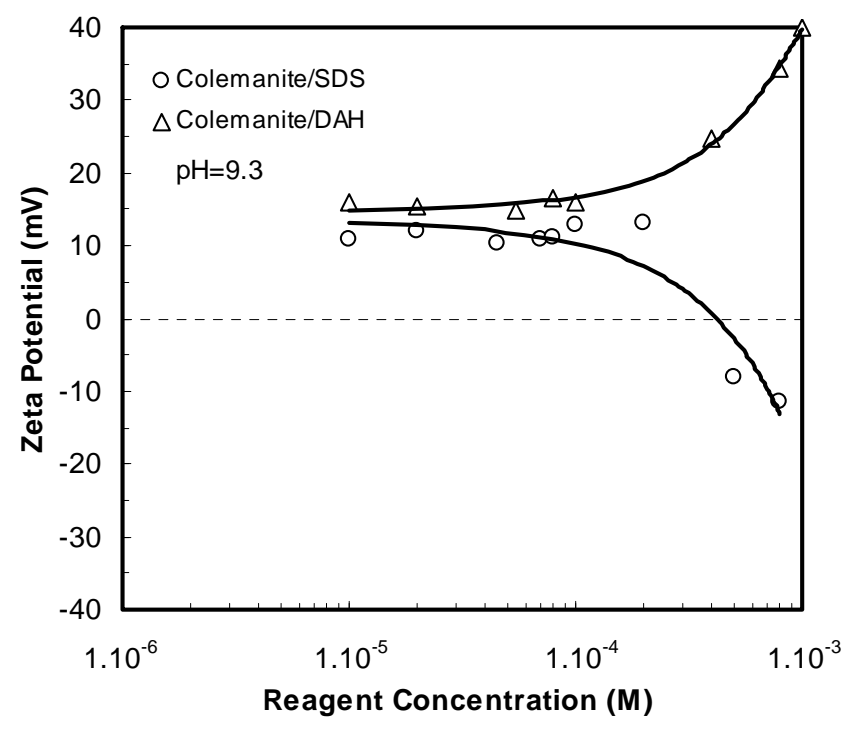

Fig. (4). Dependence of surfactant concentration on zeta potentials of colemanite at $\mathrm{pH} 9.3$ [18].

Zeta potential measurements of borax were further conducted with SDS and DAH collectors in order to test the validity of electrostatic interactions in saturated borax solutions. Fig. (5) presents the zeta potential profiles of borax in the presence of SDS and DAH. While DAH reduces the zeta potentials from -14.4 down to $-1.6 \mathrm{mV}$, SDS increases the negative charges from -14.4 up to $-26.1 \mathrm{mV}$. These results distinctly illustrate the existence of electrostatic interactions in the system.

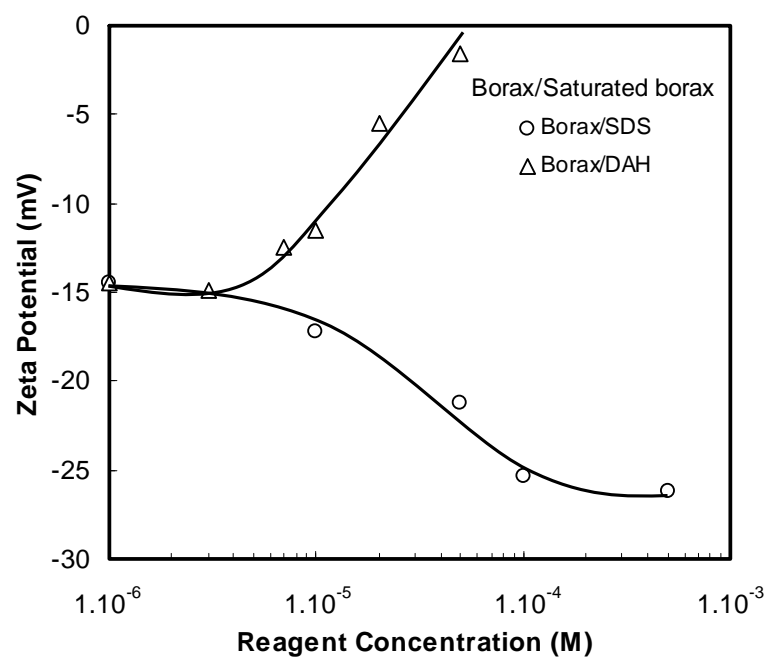

Fig. (5). Zeta potential of borax in the presence of anionic (SDS) and cationic (DAH) collectors at $\mathrm{pH} 9.3$ [27].

Zeta potential results for colemanite/SDS system exhibits an interesting behavior in that both SDS and DAH become more negative upon addition of borax (Fig. 6). As shown in Fig. (6), the addition of borate anion $\left(\mathrm{B}_{4} \mathrm{O}_{7}{ }^{2-}\right)$ makes the zeta potential of colemanite significantly more negative and thus enhances both adsorption and flotation of amine onto colemanite. Since the effect of borate is much stronger than that of amine, it outweighs the effect of amine and makes the surface less positive than expected. An explanation to this effect can be afforded in the following manner. Since SDS and borate are both anionic, they compete for positive sites on the colemanite surface. Initially, the competition favors SDS but later when the proportion of borate as pdi takes over, it rapidly increases the zeta potential of colemanite. Therefore, the increase in negative charges with SDS cannot be ascribed to the adsorption of SDS but rather to the desorption of SDS followed by adsorption of more borate on colemanite.

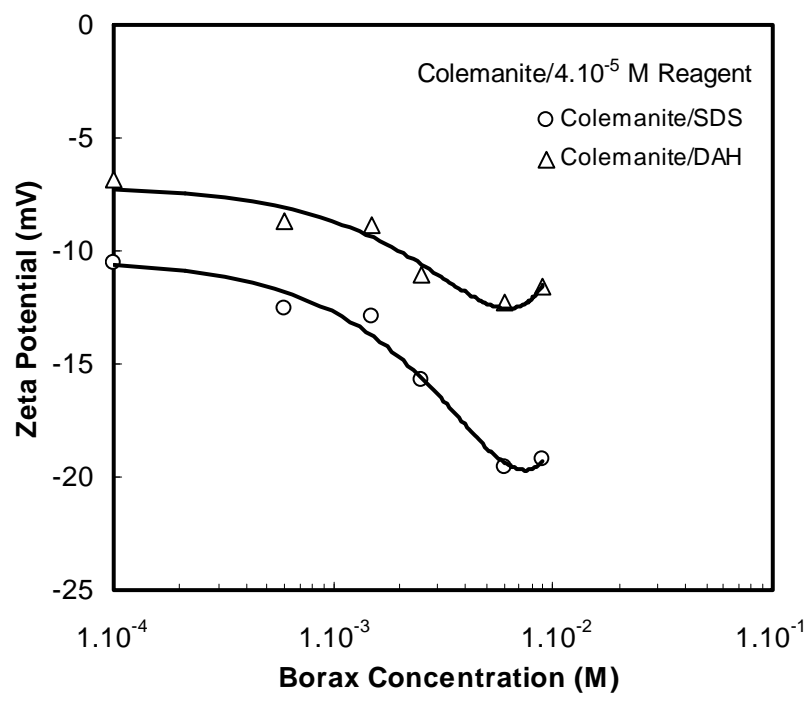

Fig. (6). Zeta potential of $1 \%$ by wt. colemanite against borax concentration in the presence of surfactants at $\mathrm{pH} 9.3$ [27] .

\subsection{Electrokinetic Properties of Boron Minerals in the Presence of Clay Minerals}

Previous studies on boron minerals revealed that clay minerals adversely affect flotation recoveries [4]. In order to study the mechanism of this process, zeta potential measurements were made for colemanite, clay, and their mixtures. The results are presented in Fig. (7). Here, the mixture is composed of $1 \mathrm{~g}$ of colemanite and $0.1 \mathrm{~g}$ of clay $\left(\mathrm{d}_{50}\right.$ of around $5 \mu \mathrm{m}$ ). It is clear that colemanite reverses its charge at $\mathrm{pH} 10.5$, whereas the clay remains negatively charged in the $\mathrm{pH}$ range studied. Interestingly, the colemanite + clay mixture acquires a charge profile similar to that of clay alone. This suggests that the negatively charged clay slimes have a strong affinity for colemanite, which induces electrostatic interactions between negatively charged clay and positively charged colemanite particles at the natural $\mathrm{pH}$ of 9.3. It has been found that as low as only $1 \%$ clay addition can reverse the charge of colemanite surface from positive to negative. Similar behavior was also found for other boron minerals under different conditions [19, 30]. However, since ulexite and borax are negatively charged in the $\mathrm{pH}$ range of practical interest, the electrostatic interactions with clay are diminished. Therefore, only the results with colemanite are shown here.

\section{FLOTATION OF BORON MINERALS}

\subsection{Effect of $\mathrm{pH}$}

The flotation of colemanite with SDS and DAH is presented in Fig. (8) as a function of pH. As seen in Fig. (8), the extent of flotation recoveries with SDS is dependent on the 
$\mathrm{pH}$. Flotation gradually decreases with increasing $\mathrm{pH}$, indicating that the surface is mainly governed by electrostatic interactions (physisorption). Flotation continues to occur until the positive charges cease to exist. Conversely, the flotation of colemanite with DAH exhibits a maximum around $\mathrm{pH} 10$, which corresponds to the formation of ion-molecular complexes $\left(\mathrm{RNH}_{2} \cdot \mathrm{RNH}_{3}\right)$. However, flotation keeps on increasing above $\mathrm{pH} 10$. This phenomenon can be explained as follows. The $\mathrm{pH}$ of maximum flotation is close to the iep, which means that the surface should become negative with increasing $\mathrm{pH}$. On the other hand, amine precipitation, which is also enhanced by the presence of solids, is visually observed above $\mathrm{pH} 10$. Such precipitation, partly in the form of surface precipitation, maintains the flotation recoveries, even at high pH's. Hancer and Celik 1993 obtained similar results with a commercial amine collector [20].

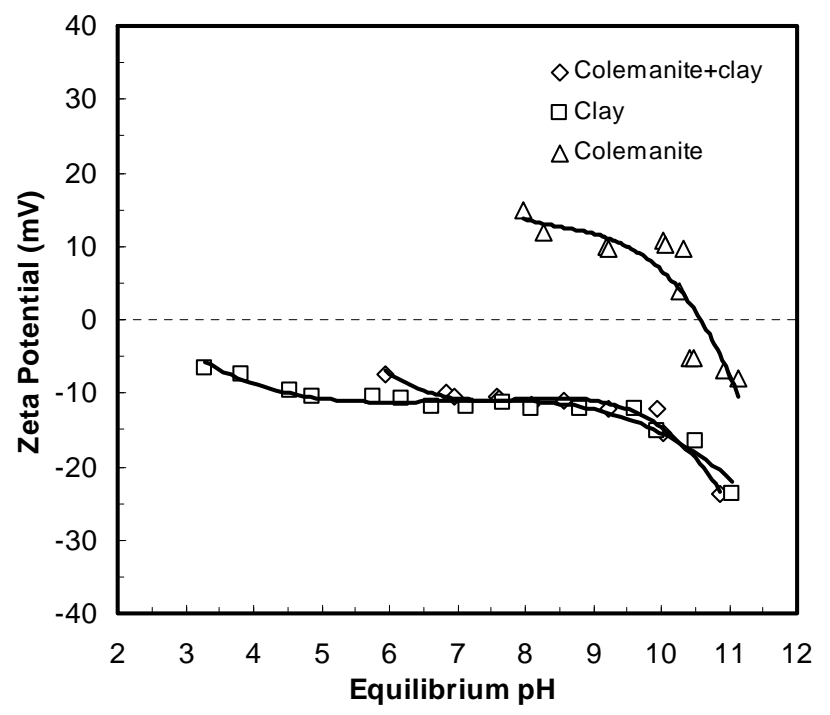

Fig. (7). Zeta potential of colemanite, clay and the mixture of colemanite and clay $(1 \mathrm{~g}+0.1 \mathrm{~g})$ as a function of $\mathrm{pH}[16]$.

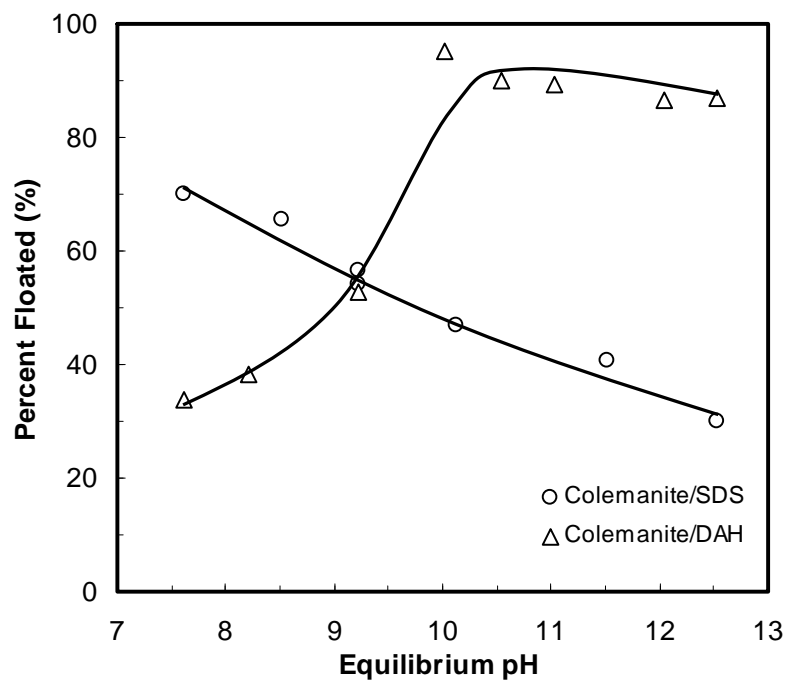

Fig. (8). Flotation of colemanite as a function of $\mathrm{pH}$ in the presence of SDS and DAH [18].

Flotation recoveries of borax vs. $\mathrm{pH}$ at a $4.10^{-6} \mathrm{M}$ surfactant concentration are illustrated in Fig. (9) for SDS and
DAH. Except for concentration differences of over one order of magnitude, the anionic flotation of borax in saturated brine solutions is similar to that of colemanite. The recoveries, however, persists at moderate levels, even at $\mathrm{pH}$ values as high as 13 . The minimum solubility of borax was found to correspond to the natural $\mathrm{pH}$ of 9.3. Thus for borax, the iep, defined as the $\mathrm{pH}$ of minimum solubility, is expected to occur in the vicinity of this $\mathrm{pH}$.

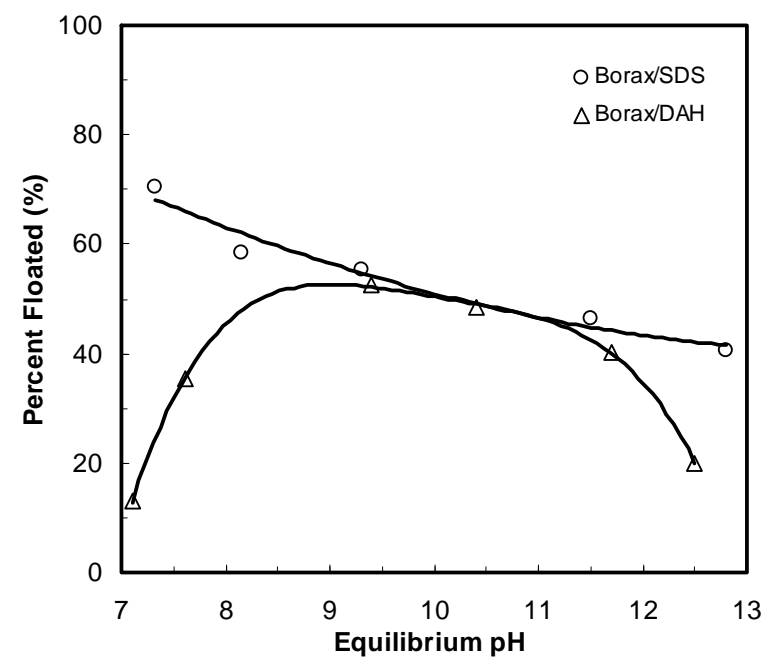

Fig. (9). Flotation of borax as a function of $\mathrm{pH}$ in the presence of anionic and cationic surfactants [18].

The flotation of borax with SDS above pH 10 is not very sensitive to $\mathrm{pH}$ where the surface charge is negative. Flotation of borax with DAH, on the other hand, exhibits a different pattern than that of colemanite. While amine flotation of colemanite remains constant above $\mathrm{pH} \mathrm{10,} \mathrm{that} \mathrm{of} \mathrm{borax}$ goes through a maximum. Visual tests at amine concentration of $4.10^{-6} \mathrm{M}$ reveal no precipitation. Thus, the absence of precipitation may be responsible for the decreased recoveries observed in Fig. (9). It is interesting to note that at a $5 \cdot 10^{-5} \mathrm{M}$ DAH concentration, complete flotation of borax was achieved at all $\mathrm{pH}$ values greater than 7 .

\subsection{Effect of Reagent Concentration}

The flotation of colemanite with SDS and DAH is presented in Fig. (10) as a function of reagent concentration. Both surfactants float colemanite in the same manner at concentrations above $1.10^{-5} \mathrm{M}$. Interestingly, the same surfactants float borax in its saturated brine at concentrations one order of magnitude lower than that of colemanite. The data illustrated in Fig. (10) exemplify the remarkable differences obtained with the flotation of two different boron minerals of the same family. While colemanite contains $\mathrm{Ca}^{2+}$ ions, the lattice structure of borax is composed of $\mathrm{Na}^{+}$ions. This characteristics feature imparts high solubility to borax. Although the collectors used are usually less soluble in concentrated brine solutions, the flotation of boron minerals is enhanced in the brine.

In the case of colemanite flotation using SDS, there appears to be a direct correlation between the onset of flotation and that of hemimicelle formation. It is known from the literature that the surface activity of the surfactant increases 
upon addition of a salt since due to salting-out effect [31]. For borax, the same idea can be advanced, provided that the extent of CMC reduction in such saturated brines. For example, the CMC of a typical anionic surfactant (alkyl sulfonate or alkyl sulfate) shifts by an order of magnitude in the presence of $0.1 \mathrm{M} \mathrm{NaCl}$ solutions, and the extent of $\mathrm{CMC}$ reduction in concentrated brines is even greater [32]. The effect of $\mathrm{KCl}$ on the surface tension is for instance found to be stronger than $\mathrm{NaCl}$. The reason for this is that $\mathrm{K}^{+}$and $\mathrm{DS}^{-}$ ions make ion-pairs at water/air interface more effectively than $\mathrm{Na}^{+}$and $\mathrm{DS}^{-}$ion [33]. Therefore, it is possible that the onset of borax flotation with SDS may also coincide with the formation of hemimicelles. However, in the case of DAH, because the Krafft temperature at high salt concentrations is possibly higher than room temperature, the formation of colloidal precipitates at the onset of sharp increase in flotation recoveries is more plausible.

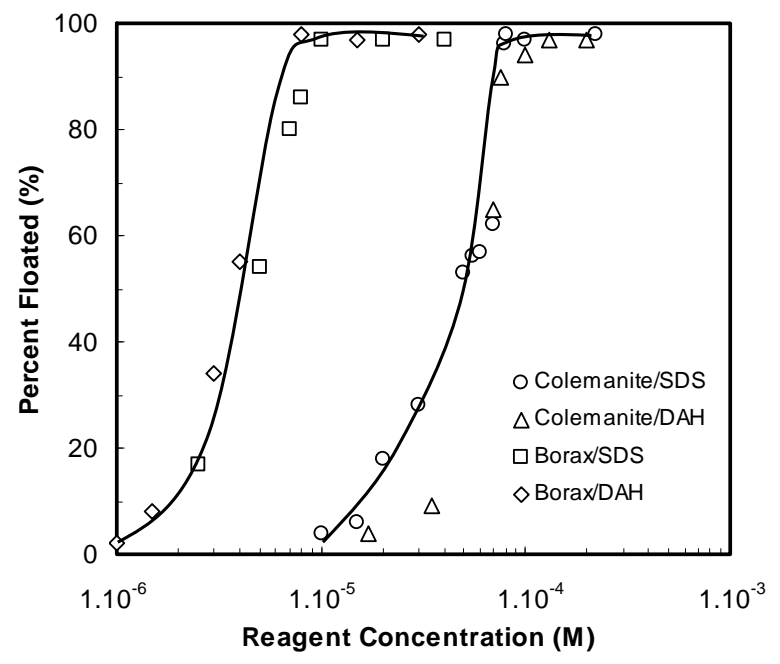

Fig. (10). Flotation recoveries of colemanite and borax vs. the concentration of anionic (SDS) and cationic (DAH) surfactants at pH 9.3 [18].

\subsection{Effect of Borax Concentration}

Flotation of colemanite vs. borax concentration is shown in Fig. (11) at $4 \cdot 10^{-5} \mathrm{M}$ of SDS and DAH additions. Flotation of colemanite with DAH as a function borax concentration yields an abrupt increase above $5.10^{-3} \mathrm{M}$ and reaches about $100 \%$ at the saturated borax solution. Unlike DAH, flotation of colemanite with SDS undergoes a shallow maximum followed by a sharp decline at $2.10^{-2} \mathrm{M}$ of borax addition. These results can be explained on the basis of electrostatic interactions in the system. The addition of borax, a pdi of colemanite, imparts negative charges to the surface of colemanite and makes it amenable to the adsorption of DAH and in turn improves the flotation recoveries. Conversely, as more borate ion is introduced into the solution, the competition of SDS with borate anion favors the adsorption of borate resulting in the desorption of SDS and consequent depression of flotation.

\subsection{Effect of Monovalent Salts}

Monovalent salts are also prevalent in the lattice structure of a number of boron minerals. The most prominent one is
$\mathrm{Na}^{+}$in the structure of borax. Apart from the effect of monovalent ions in compressing the double layers of minerals, they also modify the bulk water structure and micellization of collectors and consequently enhance surface activity of collectors [11]. There are also controversial opinions about the role of monovalent ions in the flotation of minerals. While some assert that monovalent cations and anions depending on their water-breaking and making structure modify the bulk structure of water and extrapolate the same effect all the way to the surface, others emphasize adsorption of monovalent ions at solid surfaces and their subsequent interaction with water $[11,34,35]$.

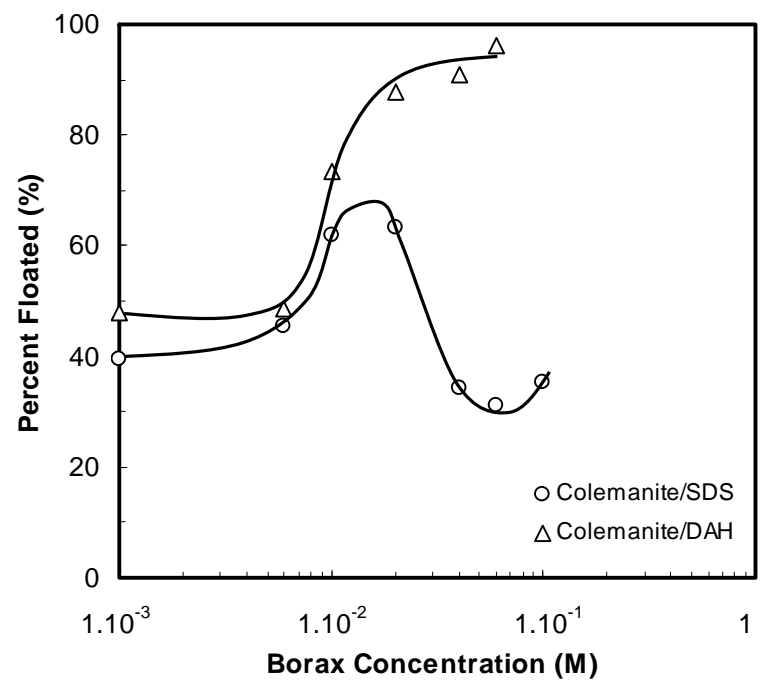

Fig. (11). Flotation of colemanite against borax with $4.10^{-5} \mathrm{M}$ concentration of SDS and DAH (pH 9.3) [27].

$\mathrm{NaCl}$ and $\mathrm{KCl}$, typical structure maker and breakers, and $\mathrm{CsCl}$, a strong structure breaker, were used to test the above mechanisms [36]. Fig. (12) illustrates the effect of monovalent salts, i.e., $\mathrm{NaCl}, \mathrm{KCl}$, and $\mathrm{CsCl}$, on the flotation of colemanite at $4.10^{-5} \mathrm{M}$ collector concentration. The percent floated is plotted as a function of salt concentration for both SDS and DAH. The highest salt concentration, i.e., $4 \mathrm{M}$, used in the experiments is close to the saturation concentrations of the respective salts. (Saturation concentrations of $\mathrm{NaCl}, \mathrm{KCl}$, and $\mathrm{CsCl}$ are respectively $5.2,4.1$, and $9.6 \mathrm{M}$ at room temperature.) The data show that both surfactants enhance the flotation of colemanite. While DAH exhibits a plateau with increasing salt concentration, SDS undergoes a maximum at salt concentrations corresponding to the precipitation-dissolution of the surfactant salt, particularly at high salt concentrations where precipitation of $\mathrm{Ca}(\mathrm{DS})_{2}$ is inevitable [37-39].

\subsection{Effect of Multivalent Ions}

Most boron minerals contain a multivalent ion as a constituent lattice ion. For instance, multivalent ions such as $\mathrm{Ba}^{2+}, \mathrm{Ca}^{2+}$, and $\mathrm{Mg}^{2+}$ were shown to activate the flotation of colemanite in the presence of SDS [40]. As shown in Fig. (13), the least soluble $\mathrm{Ba}(\mathrm{DS})_{2}$ activates colemanite most; the most soluble $\operatorname{Mg}(\mathrm{DS})_{2}$ activates colemanite the least. Metal ions depending on their solubility products with dodecyl sulfate are expected to activate colemanite. This 
is evident in the solubility products of collector salts in the order of $\mathrm{Ba}(\mathrm{DS})_{2}\left(4.8 .10^{-12}\right)<\mathrm{Ca}(\mathrm{DS})_{2}\left(2.1 .10^{-10}\right)<\mathrm{Mg}(\mathrm{DS})_{2}$ $\left(3.1 .10^{-9}\right)$. The solubility products for each ion were determined by mixing salts of multivalent ions with SDS and calculating the solubility products from the onset of precipitation using the concentrations and activity coefficients. The adsorption of these ions on the surface of colemanite was verified by adsorption measurements [40].

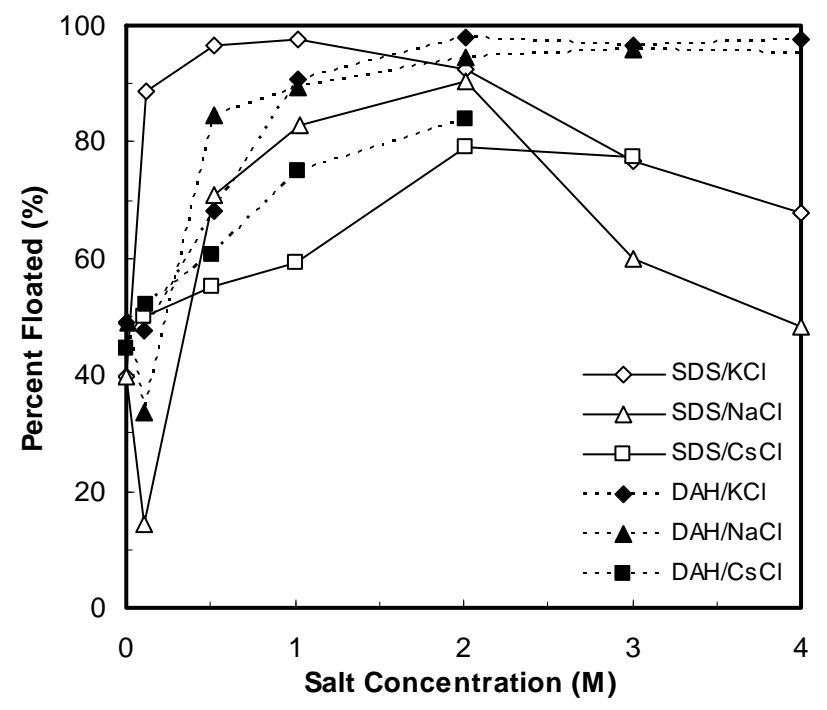

Fig. (12). Effect of monovalent salts on the flotation of colemanite with $4.10^{-5} \mathrm{M}$ of anionic (SDS) and cationic (DAH) collectors, $\mathrm{pH}$ $9.3 \pm 0.1[16]$.

As apparent from Fig. (13), the activation of colemanite with multivalent ions is marked by three distinct regions. Region I is characterized by the adsorption of multivalent ions onto the colemanite surface followed by the adsorption of anionic surfactant. Activation in Regions II and III is ascribed to the surface and bulk precipitation of metal dodecylsulfate onto the colemanite surface. The presence of surface precipitation prior to bulk precipitation has been demonstrated in a number of systems [41, 42].

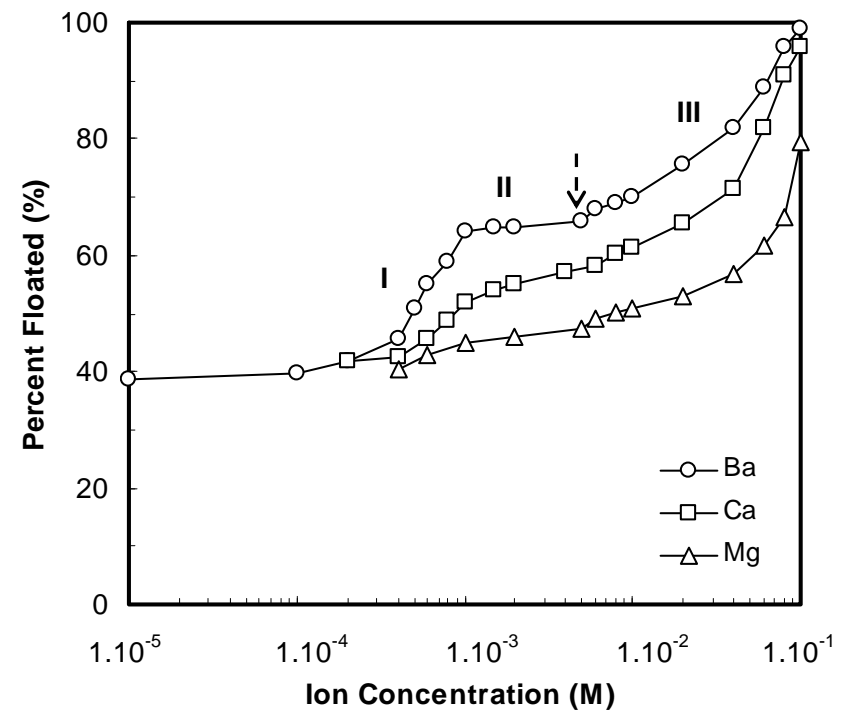

Fig. (13). Effect of multivalent ion concentration on the activation of colemanite at $\mathrm{pH} 9.3 \pm 0.1$ [16].

\subsection{Effect of Clay Slimes}

Boron minerals are generally associated with montmorillonite type clay minerals and sometimes with carbonates. Beneficiation of boron minerals at coarse sizes usually involves a pre-concentration step to separate gangue minerals in the form of scrubbing. But due to the friable nature of boron minerals the finer fractions mostly below $0.2 \mathrm{~mm}$ in size result in mixing with tailings of clay minerals. Pure colemanite mineral is readily floatable with anionic or cationic collectors. However, the flotation of colemanite ore is found to yield significantly reduced recoveries. The reason for such low recoveries was attributed to the presence of clayey slimes and also to the presence of various ions in flotation pulps [43]. Thus microflotation studies were carried out with boron minerals in the presence and the absence of clay slimes. While all boron minerals floated with both SDS and DAH in the absence of clay, they exhibited a dramatic decrease in recovery with the addition of clay. This behavior is illustrated for colemanite in Fig. (14). Various methodologies were examined to enhance the flotation of boron minerals in the presence of clay. Fig. (15) illustrates the flotation of colemanite as a function of DAH for individual colemanite and clay minerals and colemanite+clay mixture. While colemanite alone floats well with DAH, the colemanite + clay mixture and to a lesser extent the clay alone starts floating at concentrations several times higher than that of colemanite alone. Interestingly, the onset of flotation for both systems starts at about $1.10^{-4} \mathrm{M}$ DAH concentration, which corresponds to the onset of collector precipitation also. A similar phenomenon was also observed in the ulexite/clay/DAH system. In both systems it appears that the presence of colloidal precipitates facilitates the floatability of boron minerals in the presence of slimes.

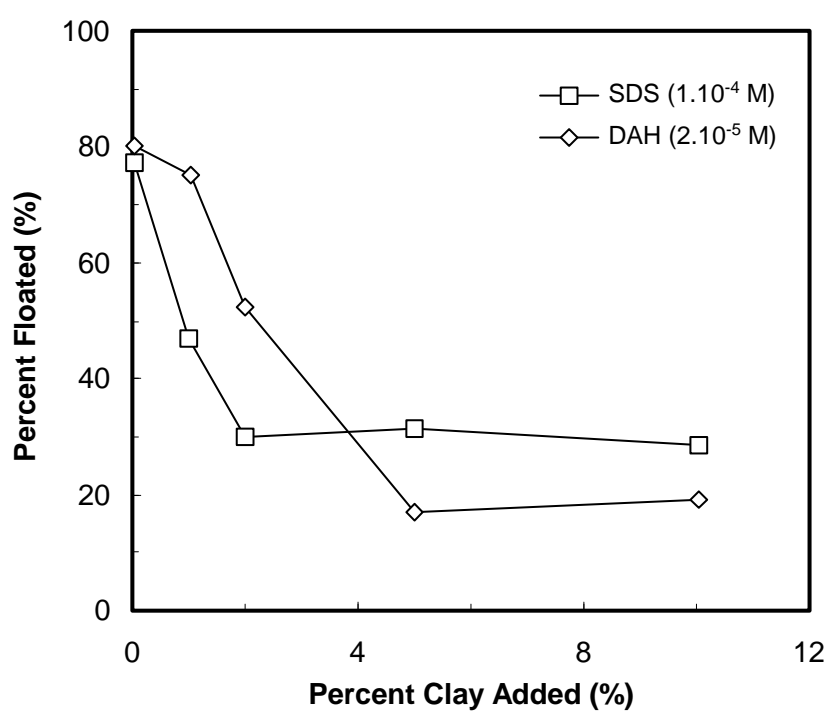

Fig. (14). Flotation of colemanite + clay mixture as a function of percent clay added in the presence of anionic (SDS) and cationic (DAH) collectors at the natural $\mathrm{pH}$ of 9.3 (The collectors were added into the mixture of colemanite and clay) [16].

These results may be explained on the basis of heterocoagulation between boron mineral, clay, and the precipitate [38]. This explanation is supported by the zeta potential measurements shown in Fig. (7) where it can be seen that the 
positive charge of colemanite at natural $\mathrm{pH} 9.3$ becomes negative in the presence of clay. Similar results were also obtained with ulexite. The SDS floats colemanite and borax well but does not float ulexite very well. The colemanite + clay mixture is found to float well with SDS particularly in the region of $\mathrm{Ca}(\mathrm{DS})_{2}$ formation. Similar results were also obtained with the ulexite/clay/SDS system [30]. It appears that the presence of colloidal precipitates in both systems facilitates the flotation of boron minerals in the presence of clay.

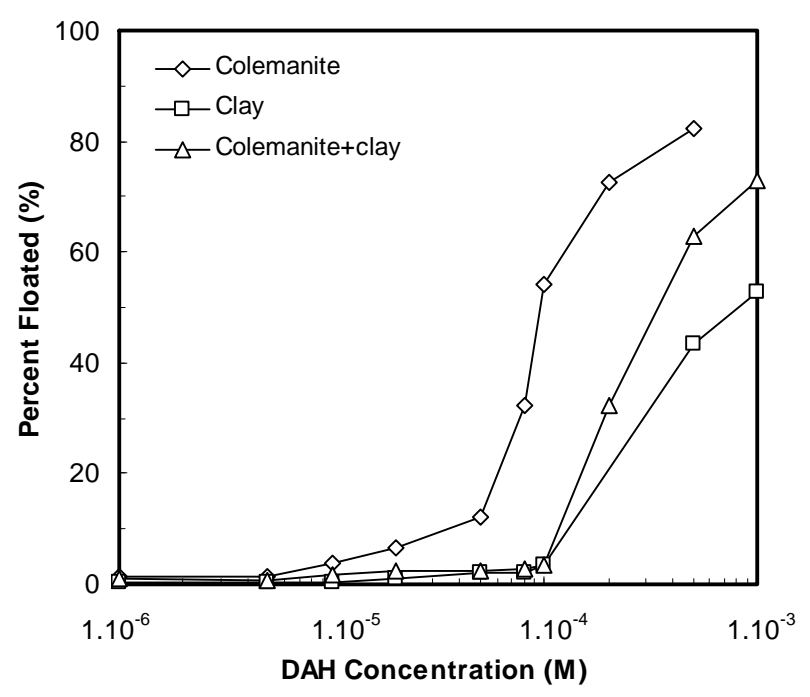

Fig. (15). Flotation of colemanite, clay, and colemanite+clay mixture as a function of $\mathrm{DAH}$ concentration at $\mathrm{pH} 9.3 \pm 0.1$ ( $0.1 \%$ clay) [16].

\subsection{Effect of Ultrasonic Treatment}

Since the attachment of clay particles at the colemanite surface is the major driving force for the decrease in colemanite flotation, a set of flotation experiments was carried out to test the ability of ultrasonic treatment to disperse the clay particles and thereby restore flotation [44-46]. The flotation recoveries versus ultrasonic treatment time presented in Fig. (16) vividly show that while in the absence of ultrasonic treatment the recovery is only 5\%, after $60 \mathrm{~s}$ of sonication full recoveries over $90 \%$ were obtained. The mechanism of this process is merely attributed to the effect of an ultrasonic field, which helps in detaching clay particles from the surface and in turn facilitates the uptake of SDS molecules by colemanite. A detailed analysis of this process shows that ultrasonic treatment not only enhances the dispersion of clay but also improves the solubility of colemanite at natural $\mathrm{pH}$ of 9.3 [47]. Similar enhancement was found with the addition of $\mathrm{Ca}^{2+}$ ions. This observed improvement was earlier explained on the basis of the formation of the surface precipitate of $\mathrm{Ca}(\mathrm{DS})_{2}$ followed by its bulk precipitate at higher SDS or $\mathrm{CaCl}_{2}$ concentrations. The synergistic effect of $\mathrm{Ca}^{2+}$ and sonication can be explained on the basis of the oppositely charged clay and $\mathrm{Ca}^{2+}$ that do not compete for adsorption sites. While clay and SDS compete for sites over colemanite, $\mathrm{Ca}^{2+}$ has no such drawback and thus directly adsorbs onto colemanite over which more SDS can adsorb. Ultrasonic treatment, on the other hand, cleans the colemanite surface from clays and makes it amenable to the adsorption of SDS. The mechanism of enhanced flotation results observed under sonication was further elaborated elsewhere $[45,47]$.

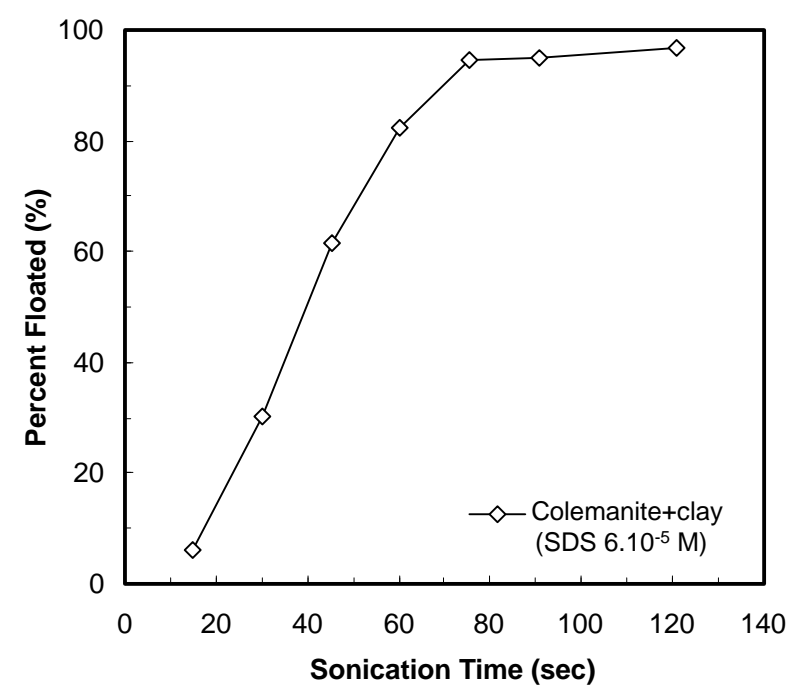

Fig. (16). In situ ultrasonic flotation for the colemanite/clay/SDS system as a function of sonication and flotation time at $\mathrm{pH} 9.3$ [47].

The zeta potential and microflotation tests showed that clay minerals coat the boron mineral surfaces and hinder the flotation response of these minerals in the presence of collectors. SEM pictures in the presence of boron minerals, clay and SDS were taken to confirm these findings [48, 49]. Figs. (17-19) shows the SEM views of ulexite, colemanite, and clay in the presence of SDS. These results clearly show that clay minerals coat the ulexite and colemanite surfaces.

\section{DISCUSSION}

The flotation chemistry of soluble salt flotation systems has been very little studied due to the inherent difficulties associated with high ionic strengths. Even existing hypothesis which have been put forth over the three decades do not surprisingly agree each other. The results presented in this study showed that for all boron minerals the potential determining ions are the constituent lattice ions, i.e., $\mathrm{B}_{4} \mathrm{O}_{7}{ }^{2-}$ and the counter ion, as well as the $\mathrm{H}^{+}$and $\mathrm{OH}^{-}$ions. Addition of model flotation collectors, e.g., SDS and DAH marginally affects the zeta potential of colemanite with $\mathrm{pH}$. The sharp changes observed in the zeta potential of colemanite vs. concentration of SDS or DAH corresponds to the solubility limits of $\mathrm{CaDSO}_{4}$ and $\mathrm{DAH}$, respectively. Especially, zeta potential of amine adsorbed onto borax revealed an abrupt increase in zeta potentials above critical DAH concentrations. Such rise in zeta potential in colemanite/DAH and ulexite/DAH systems was earlier ascribed to the presence of precipitate uptake on the mineral $[18,19]$. It is reasonable to expect that the same increase in zeta potential is induced as results of both the precipitate and colemanite acquiring the same charge. Similar results of heterocoagulation in ulexite/SDS/electrolyte system clearly illustrated that under such conditions particles, precipitates and bubbles all become hydrophobic in the region of collector-metal ion precipitation and then coagulate due to hydrophobic interactions possibly in the form of structural forces [38]. The colloidal pre- 


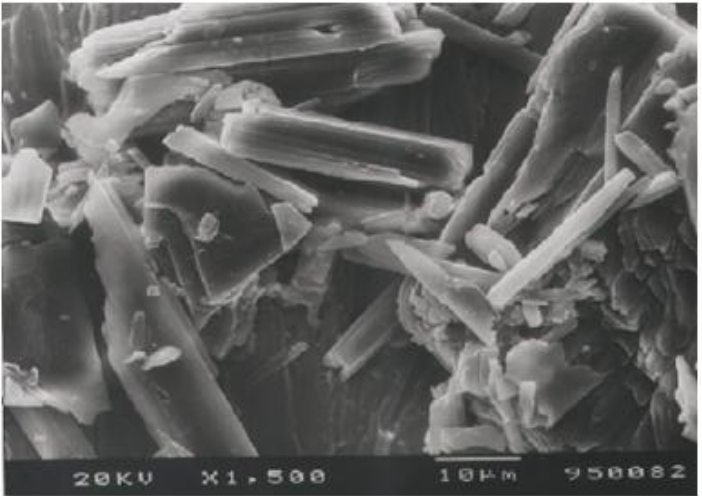

(a)

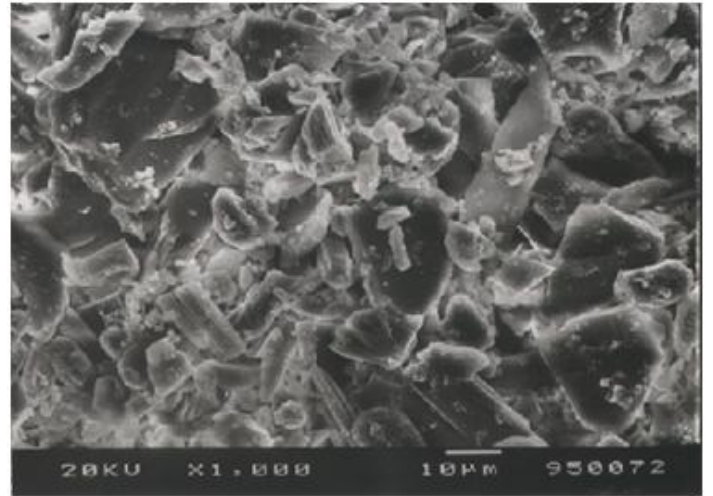

(b)

Fig. (17). SEM of (a) ulexite and (b) colemanite in the presence of SDS.

cipitates composed of long-chain surfactants have been reported to be generally hydrophobic [50].

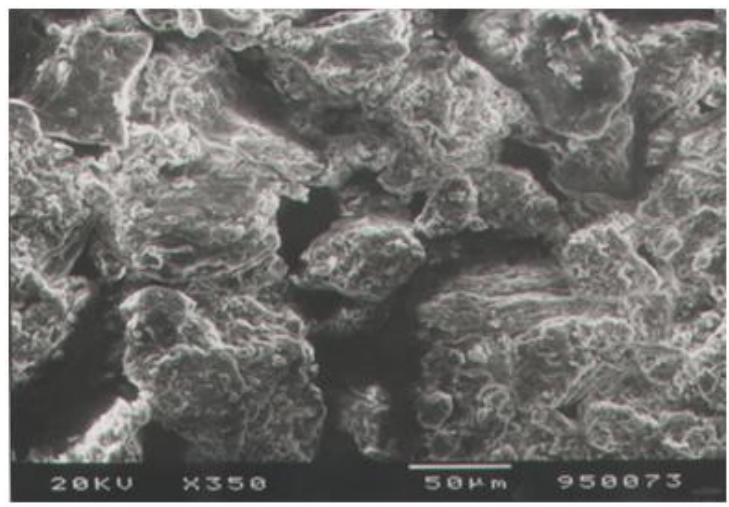

Fig. (18). SEM of clay in the presence of SDS.

The presence of DAH precipitate in boron solutions is crucial in the interpretation of flotation results, particularly those of colemanite. When amine is dissolved in water, it undergoes the following reactions [51,52].

$\mathrm{RNH}_{3} \mathrm{HCl}(\mathrm{s}) \Leftrightarrow \mathrm{RNH}_{3}{ }^{+}(\mathrm{aq})+\mathrm{Cl}^{-}$

$\mathrm{RNH}_{3}{ }^{+}(\mathrm{aq}) \Leftrightarrow \mathrm{RNH}_{2}(\mathrm{aq})+\mathrm{H}^{+}(\mathrm{aq}) \mathrm{pK}_{\mathrm{a}}=10.63$

$\mathrm{RNH}_{2}(\mathrm{aq}) \Leftrightarrow \mathrm{RNH}_{2}(\mathrm{~s}) \mathrm{pK}$ sp $=4.69$
On the other hand, the dissolution of borax in water is envisaged to occur as in Equation 3. Accordingly, the formation of amine borate and hydroborate can be written as follows:

$2 \mathrm{RNH}_{3}{ }^{+}+\mathrm{B}_{4} \mathrm{O}_{7}{ }^{2-} \Leftrightarrow\left(\mathrm{RNH}_{3}\right)_{2} \mathrm{~B}_{4} \mathrm{O}_{7}(\mathrm{~s})$

or

$\mathrm{RNH}_{3}{ }^{+}+\mathrm{HB}_{4} \mathrm{O}_{7}^{-} \Leftrightarrow \mathrm{RNH}_{3} \mathrm{HB}_{4} \mathrm{O}_{7}(\mathrm{~s})$

The various techniques used to determine the nature of the precipitate showed that the precipitate is dodeceylamine rather than the dodecylamine hydroborate complex [4]. The ions released from boron minerals have also been found to interact with SDS to form insoluble precipitates. For example, the interaction of $\mathrm{Ca}^{2+}$ with SDS results in the formation of $\mathrm{Ca}(\mathrm{DS})_{2}$. Adsorption measurements for colemanite/SDS system clearly showed the contribution of the precipitate [16].

Anionic and cationic surfactants float colemanite in the same concentration region corresponding to the formation of hemimicelles or formation of colloidal precipitates. While amines only exhibit formation of colloidal precipitates because of their high Krafft temperature, anionic surfactants may both undergo hemimicellization and precipitation at the onset of abrupt flotation recoveries [53]. Due to the salting out effect, borax, in its saturated brine, floats at concentra-

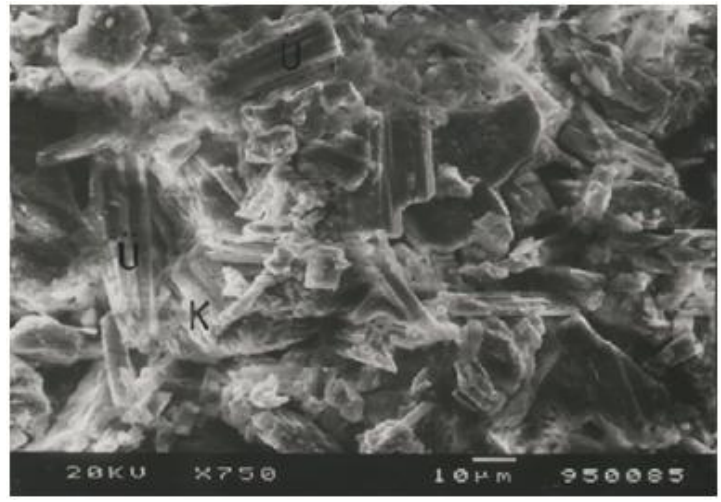

(a)

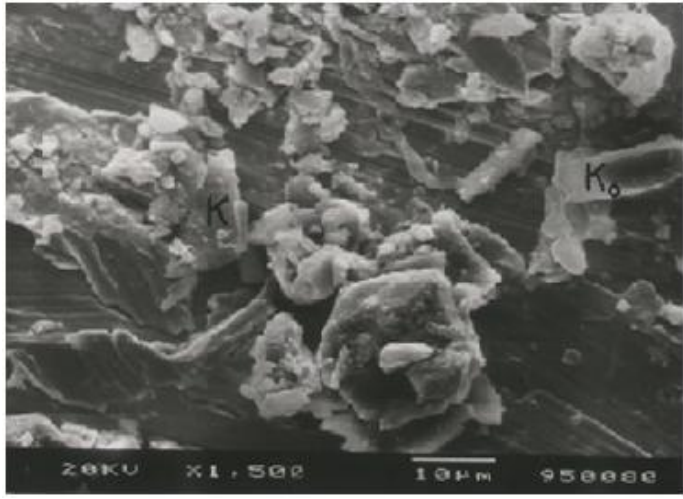

(b)

Fig. (19). SEM of (a) ulexite + clay mixture and (b) colemanite + clay mixture in the presence of SDS. 
tions one order of magnitude lower than colemanite. This salting out effect is accompanied by the enhanced surface activity of the surfactant due to the lower CMC at such high salinities. On the other hand, the flotation of colemanite and borax with SDS decreases with increasing $\mathrm{pH}$, thereby indicating the role of electrostatic interactions in the system. With a DAH concentration of $5.10^{-5} \mathrm{M}$, the flotation of colemanite exhibits a plateau at $\mathrm{pH} 10$, where maximum amounts of ion-molecular complexes form. At higher $\mathrm{pH}$ 's, the flotation of colemanite remains approximately constant due to precipitation of amine above $\mathrm{pH} 10$. In contrast, the flotation of borax with DAH $\left(4.10^{-6} \mathrm{M}\right)$ goes through a maximum at $\mathrm{pH} 10$. Above this $\mathrm{pH}$, flotation decreases due to the absence of precipitation at such low amine concentrations. In comparison to the semi-soluble boron minerals (colemanite and ulexite), borax is a soluble boron mineral and easily floats in its hydrated state but shows almost no flotation in the anhydrous form at room temperature with either cationic or anionic collectors. The waters of crystallization do not necessarily inhibit the flotation of soluble salts. For example, flotation of the hydrates of $\mathrm{MgSO}_{4}, \mathrm{Na}_{2} \mathrm{SO}_{4}$, $\mathrm{NaBr}$, and $\mathrm{NaI}$ which are the stable crystal states in water at room temperature has been demonstrated.

The role of electrostatic interactions in the flotation of most boron minerals and particularly on that of colemanite and ulexite was clearly illustrated elsewhere [19, 38]. It is generally accepted that monovalent ions are indifferent electrolytes and thus only function in the compression of an electrical double layer; this compression ceases at about $1 \mathrm{M}$ monovalent salt addition where the thickness of the electrical double layer is on the order of $1^{\circ} \mathrm{A}$. Some researchers believe that the electrostatic interactions sharply decay above $0.1 \mathrm{M}$ of salt addition. At monovalent salt levels higher than $0.1 \mathrm{M}$ and especially at $1 \mathrm{M}$, the electrostatic mechanism may be conveniently ruled out. The effect of added salt on the surface forces between two mica plates immersed in water revealed a short-range oscillatory force at high ionic strength in addition to the expected van der Waals and electrostatic double-layer forces [54-56]. This was called the hydration force and originated from the dehydration of cations at the mica surface. Accordingly, smaller, more strongly hydrated ions would produce a larger short-range repulsive force because of the greater energy required to dehydrate the smaller cations [34]. The only plausible mechanisms that can be proposed under such high ionic strength conditions are ion exchange or hydrogen bonding. However, in the case of SDS there are indications that precipitation and dissolution of $\mathrm{Ca}(\mathrm{DS})_{2}$ and possibly re-precipitation of SDS are all taking place in the system. Addition of monovalent salts is known to reduce the CMC and consequently dissolve salts of multivalent ion precipitates at lower SDS levels [57]. The precipitation appears to start at $0.1 \mathrm{M}$ salt concentration and undergoes dissolution with increasing of the salt concentration.

Earlier studies on the effect of multivalent ions on the flotation of colemanite and in particular that of $\mathrm{Ca}^{2+}$ revealed that multivalent ions are activators for colemanite and ulexite in the presence of SDS [18]. No attempt could be made to verify the same effect on borax due to limitations in the measurement of such highly soluble solutions. Since borate anion $\left(\mathrm{B}_{4} \mathrm{O}_{7}{ }^{2-}\right)$ is an indispensable in the lattice structure of all boron minerals, it was of interest to find out its effect on the flotation of a model mineral, colemanite. However, it is believed that these results can be extended to all boron minerals.

The flotation results with clay minerals showed that even as little as $1 \%$ of clay addition can reduce the flotation recoveries significantly. This is ascribed to the uptake of negatively charged clay mineral onto positive sites at the surface of boron minerals as slime coating. Although zeta potential and flotation results clearly demonstrate the presence of slime coating, the coating mechanism is not well established. Atomic force microscopy (AFM) has been used to reveal the extent of interactions between particles (boron-clay) and particle and collector molecules to quantitatively determine the interaction of clay particles with colemanite as a model boron mineral $[30,58]$. The clay coating was also proven with SEM pictures taken with boron mineral, clay, and their mixtures in the presence of SDS.

Finally, ultrasonic treatment of the pulp enhanced adsorption of flotation chemicals by detaching clay particles from the colemanite surface. Ultrasonic field during conditioning appears to be promising for reducing the dosage of chemical reagents. In addition, conditioning with in situ sonication requires a collector addition several times lower than that prepared by conventional conditioning.

\section{CONCLUSIONS}

Electrokinetic studies indicate that for all boron minerals the potential-determining ions are the constituent lattice ions, i.e., $\mathrm{B}_{4} \mathrm{O}_{7}{ }^{2-}$ and the counterion, as well as the $\mathrm{H}^{+}$and $\mathrm{OH}^{-}$ ions, which control the ratio of $\mathrm{HCO}_{3}{ }^{-} / \mathrm{CO}_{3}{ }^{2-}$. Flotation of colemanite with both anionic (SDS) and cationic (DAH) collectors in the absence of salt is attributed to electrostatic interactions in the system. Flotation of colemanite in the presence of monovalent ions is enhanced. It appears that, for semisoluble minerals, the effect of monovalent salt addition is to improve the salting out of collectors and enhance their consequent surface activity and micellization. Multivalent cations have also been shown to act as activators in boron flotation systems. The precipitation of collector colloids in flotation pulps followed by their attachment to oppositely charged surfaces through heterocoagulation has been found to lead to improved recoveries both in the presence and in the absence of clay slimes. This phenomenon is particularly enhanced at $\mathrm{pH}$ values where the multivalent cations undergo hydrolysis. A common problem encountered in all types of boron minerals is the presence of significant amounts of clay-type minerals, which adversely affect flotation recoveries due to slime coatings. It is found that even as little as $1 \%$ of clay addition can reduce the flotation recoveries considerably. Boron minerals plus clay mixtures acquire a charge profile similar to that of clay itself. This is ascribed to the uptake of negatively charged clay mineral onto positive sites at the surface of boron minerals as slime coating.

\section{ACKNOWLEDGEMENTS}

Financial support for these studies during 1996-2000 was provided by NSF (Grant No. INT-9512813) and TUBITAK of Turkey.

\section{REFERENCES}

[1] S. R. I. Consulting, Boron Minerals and Chemicals: CEH Marketing Research Report, 2008. 
[2] P. W. Harben, Borates:The Industrial Minerals Handybook, $2^{\text {nd }}$ ed. Metal Bulletin PLC: London, 1995.

[3] P. W. Harben and E. M. Dickson, "Borates: Economic Geology and Production," In: J. M. B. A. S. J. Lefond, Ed. American Institute of Mining, Metallurgical, and Petroleum Engineers, AIME, New York, 1985 , p. 4.

[4] Y. Akin, I. Gulgonul, and M. S. Celik, "Interaction of amine with borate species in boron flotation pulps," in SME Annual Meeting, Denver, CO., 1997, pp. 97-135.

[5] D. W. Fuerstenau and M. C. Fuerstenau, "Ionic size in flotation collection of alkali halides," Transactions of the American Institute of Mining, Metallurgical, and Petroleum Engineers, vol. 4156-B, p. 205, 1956.

[6] J. Rogers and J. H. Schulman, "A mechanism of the selective flotation of soluble salts in the saturated solutions. In: Electrical phenomena and solid/liquid interface," in Proceedings of the Second Internatioal Congress of Surface Activity III, 1957, pp. 243251.

[7] H. Schubert, "The mechanisms of collector adsorption on salt-type minerals from solutions containing high electrolyte concentrations," Aufbereitungs-Technik, vol. 29, pp. 427-435, 1988.

[8] M. R. Yalamanchili, J. J. Kellar, and J. D. Miller, "Adsorption of collector colloids in the flotation of alkali halide particles.," International Journal of Mineral Processing, vol. 39, pp. 137-153, 1993.

[9] J. D. Miller, M. R. Yalamanchili, and J. J. Kellar, "Surface charge of alkali halide particles as determined by laser-doppler electrophoresis," Langmuir, vol. 8, pp. 1464-1469, 1992.

[10] M. Hancer and J. D. Miller, "The flotation chemistry of potassium double salts: schoenite, kainite, and carnallite," Minerals Engineering, vol. 13, pp. 1483-1493, 2000.

[11] M. Hancer, M. S. Celik, and J. D. Miller, "The significance of interfacial water structure in soluble salt flotation systems," Journal of Colloid and Interface Science vol. 235, pp. 150-161, 2001.

[12] O. Ozdemir, C. Karaguzel, A. V. Nguyen, M. S. Celik, and J. D. Miller, "Contact angle and bubble attachment studies in the flotation of trona and other soluble carbonate salts," Minerals Engineering, vol. 22, pp. 168-175, 2009a.

[13] O. Ozdemir, M. S. Celik, Z. S. Nickolov, and J. D. Miller, "Water structure and its influence on the flotation of carbonate and bicarbonate salts," Journal of Colloid and Interface Science, vol. 314, pp. 545-551, 2007.

[14] O. Ozdemir, S. I. Karakashev, A. V. Nguyen, and J. D. Miller, "Adsorption of carbonate and bicarbonate salts at the air-brine interface," International Journal of Mineral Processing, vol. 81, pp. 149-158, 2006.

[15] H. Du, J. Liu, O. Ozdemir, A. V. Nguyen, and J. D. Miller, "Molecular features of the air/carbonate solution interface," Journal of Colloid and Interface Science, vol. 318, pp. 271-277, 2008.

[16] M. S. Celik, M. Hancer, and J. D. Miller, "Flotation chemistry of boron minerals," Journal of Colloid and Interface Science, vol. 256, pp. 121-131, 2002.

[17] M. S. Celik and E. Yasar, "Electrokinetic properties of some hydrated boron minerals," Journal of Colloid and Interface Science, vol. 173, pp. 181-5, 1995.

[18] M. S. Celik, S. Atak, and G. Onal, "Flotation of boron minerals," Minerals and Metallurgical Processing, vol. 10, pp. 149-153, 1993.

[19] M. S. Celik and R. Bulut, "Mechanism of selective flotation of sodium-calcium borates with anionic and cationic collectors," Separation Science and Technology, vol. 31, pp. 1817-1829, 1996.

[20] M. Hancer and M. S. Celik, "Flotation of mechanism of boron minerals," Separation Science and Technology, vol. 28, pp. 17031714, 1993.

[21] Ş. G. Özkan, "A practical approach to solubility of colemanite ores," The Institution of Mining and Metallurgy Transactions, vol. Section C, pp. C53-C55, 1999.

[22] Ş. G. Özkan, "Investigation of solubility parameters prior to processing of Kestelek colemanite," In: $8^{\text {th }}$ International Mineral Processing Symposium, Antalya, 2000, pp. 545-548.

[23] M. S. Celik and M. Hancer, "Flotation of boron minerals," Minerals and Metallurgical Processing, vol. 11, pp. 123-124, 1994.

[24] B. Yarar, Borates: Economic Geology and Production. New York: AIME, 1985.
[25] M. Alkan, M. M. Kocakerim, and S. Colak, "Dissolution kinetics of colemanite in water saturated by carbon dioxide," Journal of Chemical Technology \& Biotechnology A, vol. 35, pp. 215-222, 1985.

[26] M. Alkan, M. Oktay, M. M. Kocakerim, and Z. Karagolge, "Dissolution kinetics of some borates mineral in $\mathrm{CO} 2$-saturated water," Hydrometallurgy, vol. 26, pp. 255-262, 1991.

[27] M. Muduroglu, M. S. Celik, M. Hancer, and J. D. Miller, "Electrokinetic behavior of borax in saturated solutions and its role in flotation," In Mineral Processing on the Verge of the $21^{\text {st }}$ Century Proceedings of the $8^{\text {th }}$ International Mineral Processing Symposium, Antalya, Turkey, 16-18 October 2000, pp. 231-236.

[28] J. S. Laskowski, "Challenges in Mineral Processing," in SME, Littleton, CO, 1989, p. 15.

[29] M. S. Çelik, A. Goyal, E. D. Manev, and P. Somasundaran, "The role of surfactant precipitation and redissolution in the adsorption of sulfonate on minerals," Society of Petroleum Engineers Journal, pp. 233-239, 1984.

[30] J. D. Miller and M. S. Celik, "Recovery of borax from saturated salt solutions," Final Report submitted to NSF (Grant No. INT9512813) and TUBITAK of Turkey, 2000.

[31] J. C. Eriksson, S. Ljunggren, and P. M. Claesson, "A phenomenological theory of long-range hydrophobic attraction forces based on a square-gradient variational approach," Journal of the Chemical Society, Faraday Transactions 2, vol. 85, pp. 163176, 1989.

[32] O. Ozdemir, S. I. Karakashev, A. V. Nguyen, and J. D. Miller, "Adsorption and surface tension analysis of concentrated alkali halide brine solutions," Minerals Engineering, vol. 22, pp. 263271,2009 b.

[33] S. Karakashev, R. Tsekov, and E. Manev, "Adsorption of alkali dodecyl sulfates on air/water surface," Langmuir, vol. 17, pp. 54035405, 2001.

[34] M. Colic, G. V. Franks, M. L. Fisher, and F. F. Lange, "Effect of counterion size on short range repulsive forces at high ionic strengths," Langmuir, vol. 13, pp. 3129-3135, 1997.

[35] S. W. Clark and S. R. B. Cooke, "Adsorption of calcium, magnesium, and sodium ion by quartz," Transactions of the American Institute of Mining, Metallurgical and Petroleum Engineers, vol. 241, pp. 56-64, 1968.

[36] P. Somasundaran and H. S. Hanna, "Adsorption of sulfonates on reservoir rocks," Society of Petroleum Engineers Journal, vol. 19, pp. 221-232, 1979.

[37] M. C. Fuerstenau and W. F. Cummins, "The role of basic aqueous complexes in anionic flotation of quartz," Transactions of the American Institute of Mining, Metallurgical, and Petroleum Engineers vol. 241, pp. 56-61, 1968.

[38] M. S. Celik, E. Yasar, and H. El-Shall, "Flotation of heterocoagulated particulates in ulexite/SDS/electrolyte system," Journal of Colloid and Interface Science, vol. 203, pp. 254-259, 1998.

[39] I. Krznaric, J. Bozic, and N. Kallay, "Association and precipitation of alkaline earth dodecyl sulphates in aqueous media," Croatica Chemica Acta, vol. 52, pp. 183-189, 1979.

[40] M. S. Celik, M. Hancer, G. Atesok, and O. F. Emrullahoglu, Beneficiation of phosphates: Theory and practice. Littleton, $\mathrm{CO}$, 1993.

[41] K. Ananthpadmanabhan and P. Somasundaran, "Surface precipitation of inorganics and surfactants and its role in adsorption and flotation," Colloids and Surfaces, vol. 13, pp. 151-167, 1985.

[42] J. S. Hu, M. Misra, and J. D. Miller, "Characterization of adsorbed oleate species at the fluorite surface by FTIR spectroscopy " International Journal of Mineral Processing, vol. 18, pp. 73-84, 1986.

[43] S. G. Ozkan and A. Acar, "Investigation of impact of water type on borate ore flotation," Water Research, vol. 38, pp. 1773-1778, 2004.

[44] Ş. G. Özkan and T. J. Veasey, "The effect of slime coatings on colemanite flotation," In: $5^{\text {th }}$ International Mineral Processing Symposium, Kapadokya, 1994, pp. 205-210.

[45] S. G. Özkan and T. J. Veasey, "Effect of simultaneous ultrasonic treatment on colemanite flotation," In: Proceedings of the $6^{\text {th }}$ International Mineral Processing Symposium, 1996, pp. 277-281.

[46] Ş. G. Özkan and H. Z. Kuyumcu, "Investigation of effects of ultrasonic waves on various phases of froth flotation," in: $23^{\text {rd }}$ 
International Mineral Processing Congress, Istanbul, 2006, pp. 598-603.

[47] M. S. Celik, I. Elma, M. Hancer, and J. D. Miller, "Effect of in-situ ultrasonic treatment on the floatability of slime coated colemanite," Innovations in Mineral and Coal Processing: In: $7^{\text {th }}$ International Mineral Processing Symposium, pp. 153-157, 1998.

[48] İ. Gülgönül, O. Özdemir, U. Mart, and M. S. Çelik, "Slime coating mechanism in the anionic flotation of ulexite," presented at the International Boron Symposium, Kütahya, Türkiye, 2002.

[49] I. Gulgonul, C. Karaguzel, M. Cinar, and O. Ozdemir, "Mechanism of slime coating of clay particles in anionic flotation of colemanite (in Turkish)," Journal of Clay Science and Technology (Kibited), vol. 1, pp. 47-54, 2008.

[50] R. J. Roman, M. C. Fuerstenau, and D. Seidel, "Mechanisms of soluble salt flotation. Part I," Transactions of the American Institute of Mining, Metallurgical, and Petroleum Engineers, vol. 241, pp. 56-65, 1969.

[51] K. Ananthpadmanabhan, P. Somasundaran, and T. W. Healy, "Chemistry of oleate and amine solutions in relation to flotation," Transactions of the American Institute of Mining, Metallurgical, and Petroleum Engineers, vol. 266, pp. 2003-2009, 1979.

[52] R. M. Smith and A. E. Martel, Amines: Critical Stability of Constants. vol. 2. New York: Plenum Press, 1975.
[53] E. Burdukova, J. S. Laskowski, and G. R. Forbes, "Precipitation of dodecyl amine in $\mathrm{KCl}-\mathrm{NaCl}$ saturated brine and attachment of amine particles to $\mathrm{KCl}$ and $\mathrm{NaCl}$ surfaces," International Journal of Mineral Processing, vol. 93, pp. 34-40, 2009.

[54] J. N. Israelachvili, "Forces between surfaces in liquids," Advances in Colloid and Interface Science, vol. 16, pp. 31-47, 1982.

[55] R. M. Pashley, "Hydration forces between mica surfaces in electrolyte solutions," Advances in Colloid and Interface Science, vol. 16, pp. 57-62, 1982.

[56] J. N. Israelachvili and R. M. Pashley, "Molecular layering of water at surfaces and origin of repulsive hydration forces," Nature, vol. 306, pp. 249-250, 1983.

[57] M. S. Celik and P. Somasundaran, "Effect of chain length on dissolution of calcium sulfonate precipitates," Journal of Colloid and Interface Science, vol. 122, pp. 163-170, 1988.

[58] S. Veeramasuneni, M. R. Yalamanchili, J. D. Miller, and M. S. Celik, "Adsorption of model collector colloids at the surface of colemanite as characterized by optical and atomic force microscopy," in Changing Scopes in Mineral Processing, In: Proceedings of the 6th International Mineral Processing Symposium, Istanbul, 1996, pp. 215-220.

(C) Özdemir and Çelik; Licensee Bentham Open.

This is an open access article licensed under the terms of the Creative Commons Attribution Non-Commercial License (http://creativecommons.org/licenses/by-nc/3.0/) which permits unrestricted, non-commercial use, distribution and reproduction in any medium, provided the work is properly cited. 